Article

\title{
A New Triterpenoid from Teucrium viscidum
}

Xincai Hao ${ }^{1, \dagger}$, Jinwen Zhang ${ }^{2, \dagger}$, Guangxin Xia ${ }^{3}$, Yongbo Xue ${ }^{1}$, Zengwei Luo ${ }^{1}$, Yanyan Si ${ }^{1}$, Guangmin Yao ${ }^{1, *}$ and Yonghui Zhang ${ }^{1, *}$

1 Hubei Key Laboratory of Natural Medicinal Chemistry and Resource Evaluation, School of Pharmacy, Tongji Medical College, Huazhong University of Science and Technology, Wuhan 430030, China

2 Tongji Hospital Affiliated to Tongji Medical College, Huazhong University of Science and Technology, Wuhan 430030, China

3 Central Research Institute, Shanghai Pharmaceutical Holding Co. Ltd, 898 Halei Road, Zhangjiang Hi-Tech Park, Shanghai 201203, China

$\dagger$ These authors contributed equally to this work.

* Authors to whom correspondence should be addressed; E-Mails: gyap@mail.hust.edu.cn (G.Y.); zhangyh@mails.tjmu.edu.cn (Y.Z.); Tel.: +86-15171484550 (G.Y.); +86-27-8369-2311 (Y.Z.); Fax: +86-27-8369-2762 (G.Y.\& Y.Z.).

Received: 3 December 2012; in revised form: 1 January 2013 / Accepted: 7 January 2013 / Published: 21 January 2013

Abstract: A new ursane-type triterpenoid, $3 \beta$-hydroxy-urs-30- $p$-Z-hydroxycinnamoyloxy12-en-28-oic-acid (1), together with three known triterpenoids, $3 \beta$-hydroxy-urs-30- $p$ - $E$ -

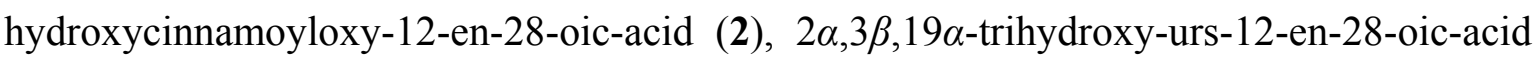
(3), and ursolic acid (4), four known lignans, pinoresinol (5), $9 \alpha$-hydroxypinoresinol (6), $(+)$-medioresinol (7), and (+)-kobusin (8), and two steroids, $\beta$-sitosterol (9), and daucosterol (10), were isolated from the whole parts of Teucrium viscidum. Their structures were established by a combination of spectroscopic data analysis, besides comparison with literature data. Compounds $\mathbf{1 - 4}$ were evaluated for their inhibitory activities against $11 \beta$-hydroxysteroid dehydrogenase 1 (11 $\beta$-HSD1).

Keywords: Teucrium viscidum; triterpenoids; lignans; $11 \beta$-HSD1 


\section{Introduction}

Teucrium viscidum Blume (Lamiaceae), known as Shan-Huo-Xiang in China, is an annual herb, whose whole parts are used as a traditional Chinese medicine to treat hemoptysis, hematemesis, pulmonary abscesses, traumatic injuries, and bites of rabies-stricken dogs or venomous snakes [1]. Previous phytochemical studies on T. viscidum have resulted in the isolation of several neoclerodane diterpenoids [2-5]. In the course of search for novel natural products from traditional Chinese medicines, a new triterpenoid 1, together with nine known compounds $\mathbf{2 - 1 0}$, were isolated from the whole parts of $T$. viscidum. In this paper, we report the isolation and structural elucidation of compounds 1-10 (Figure 1), as well as the inhibitory activities against 11 $\beta$-HSD1 of compounds 1-4.

Figure 1. Structures of compounds 1-10.

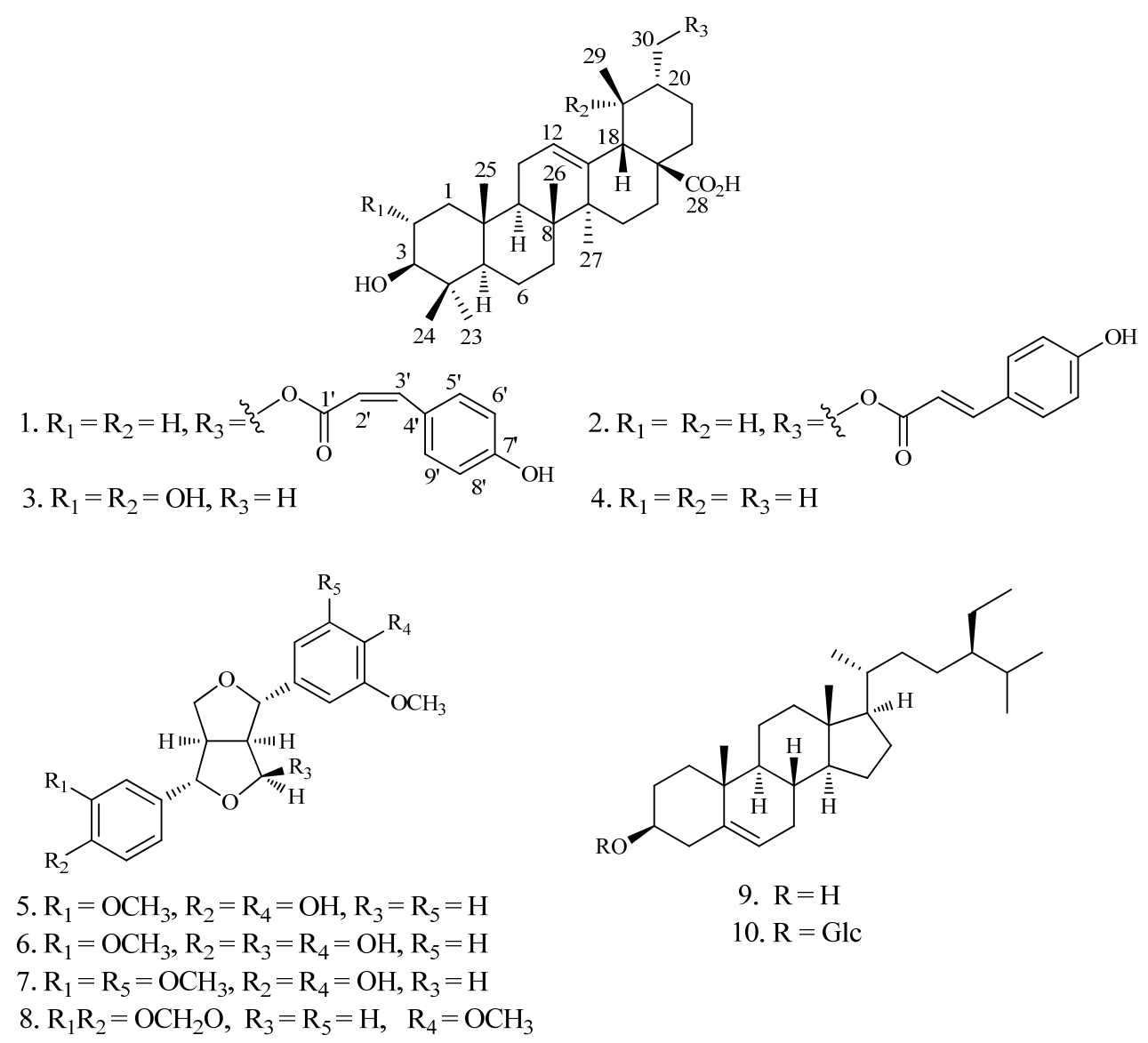

\section{Results and Discussion}

The acetone extract of the air-dried whole parts of $T$. viscidum was suspended in water and successively partitioned with petroleum ether, $\mathrm{CHCl}_{3}$, and EtOAc. The $\mathrm{CHCl}_{3}$ fraction was subjected to column chromatography to afford one new triterpenoid 1, along with nine known compounds,

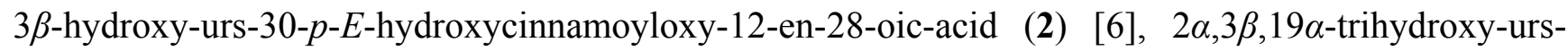
12-en-28-oic-acid (3) [7], ursolic acid (4) [7], pinoresinol (5) [8], 9 $\alpha$-hydroxypinoresinol (6) [9], (+)-medioresinol (7) [10], (+)-kobusin (8) [11], $\beta$-sitosterol (9) [12], and daucosterol (10) [12]. The known compounds were identified on the basis of NMR spectroscopic analyses and comparison with those reported in the literature (Figure 1). 
Compound 1 was obtained as an amorphous powder. Its molecular formula, $\mathrm{C}_{39} \mathrm{H}_{54} \mathrm{O}_{6}$, could be deduced from the (+)-HRESIMS peak at $\mathrm{m} / z$ 641.3799 [M+Na] ${ }^{+}$(calcd. for $\mathrm{C}_{39} \mathrm{H}_{54} \mathrm{O}_{6} \mathrm{Na}^{+}, 641.3818$ ). The IR spectrum showed absorption bands for hydroxyl $\left(3729 \mathrm{~cm}^{-1}\right)$, carbonyl $\left(1685 \mathrm{~cm}^{-1}\right)$ and benzene ring $\left(1602 \mathrm{~cm}^{-1}\right)$ functions. The ${ }^{1} \mathrm{H}-\mathrm{NMR}$ spectrum of 1 (Table 1) showed five tertiary methyl singlets at $\delta_{\mathrm{H}} 0.92(3 \mathrm{H}, \mathrm{s}), 1.05(3 \mathrm{H}, \mathrm{s}), 1.08(3 \mathrm{H}, \mathrm{s}), 1.23(3 \mathrm{H}, \mathrm{s})$, and $1.26(3 \mathrm{H}, \mathrm{s})$, one secondary methyl doublet protons at $\delta_{\mathrm{H}} 1.09(3 \mathrm{H}, \mathrm{d}, J=6.0 \mathrm{~Hz})$, three protons attached to oxygenated carbons at $\delta_{\mathrm{H}} 4.50$ $(1 \mathrm{H}, \mathrm{dd}, J=3.2 \mathrm{~Hz}, 11.2 \mathrm{~Hz}), 4.27(1 \mathrm{H}, \mathrm{dd}, J=7.2 \mathrm{~Hz}, 11.2 \mathrm{~Hz}), 3.48(1 \mathrm{H}, \mathrm{dd}, J=6.8 \mathrm{~Hz}, 9.2 \mathrm{~Hz})$, three olefinic protons at $\delta_{\mathrm{H}} 7.03(1 \mathrm{H}, \mathrm{d}, J=12.8 \mathrm{~Hz}), 6.09(1 \mathrm{H}, \mathrm{d}, J=12.8 \mathrm{~Hz}), 5.52(1 \mathrm{H}, \mathrm{t}, J=3.2 \mathrm{~Hz})$, and a $p$-disubstituted benzene ring at $\delta_{\mathrm{H}} 8.09(\mathrm{~d}, J=8.4 \mathrm{~Hz}, 2 \mathrm{H})$ and $7.22(\mathrm{~d}, J=8.4 \mathrm{~Hz}, 2 \mathrm{H})$. The ${ }^{13} \mathrm{C}-\mathrm{NMR}$, DEPT, and HSQC spectra for $\mathbf{1}$ exhibited thirty nine carbon signals differentiated as six methyls, ten methylenes (including an oxygenated), thirteen methines (including seven olefins and an oxygenated), and ten quaternary carbons (including two carbonyls, an olefin, and an oxygenated).

Table 1. ${ }^{1} \mathrm{H}-\mathrm{NMR}(400 \mathrm{MHz})$ and ${ }^{13} \mathrm{C}-\mathrm{NMR}(100 \mathrm{MHz})$ Spectral Data of Compound $\mathbf{1}$ in $\mathrm{C}_{5} \mathrm{D}_{5} \mathrm{~N}$ ( $\delta$ in ppm, $J$ in $\mathrm{Hz}$ ).

\begin{tabular}{|c|c|c|c|c|c|}
\hline NO. & $\delta_{\mathrm{H}}$ & $\delta_{\mathrm{C}}$ & NO. & $\delta_{\mathrm{H}}$ & $\delta_{\mathrm{C}}$ \\
\hline $\begin{array}{l}1 \alpha \\
1 \beta\end{array}$ & $\begin{array}{l}1.00 \mathrm{~m} \\
1.58 \mathrm{~m}\end{array}$ & 39.6 & $20 \beta$ & $1.43 \mathrm{~m}$ & 44.4 \\
\hline 2 & 1.86 overlap & 28.6 & $\begin{array}{l}21 \alpha \\
21 \beta\end{array}$ & $\begin{array}{l}1.62 \mathrm{~m} \\
1.79 \mathrm{~m}\end{array}$ & 26.1 \\
\hline $3 \alpha$ & $3.48 \mathrm{dd}(6.8,9.2)$ & 78.6 & $\begin{array}{l}22 \alpha \\
22 \beta\end{array}$ & $\begin{array}{l}2.07 \text { overlap } \\
1.96 \text { overlap }\end{array}$ & 37.4 \\
\hline 4 & & 39.9 & 23 & $1.26 \mathrm{~s}$ & 29.3 \\
\hline $5 \alpha$ & $0.88 \mathrm{~m}$ & 56.3 & 24 & $1.05 \mathrm{~s}$ & 17.0 \\
\hline $\begin{array}{l}6 \alpha \\
6 \beta\end{array}$ & $\begin{array}{l}1.59 \mathrm{~m} \\
1.39 \mathrm{~m}\end{array}$ & 19.3 & 25 & $0.92 \mathrm{~s}$ & 16.2 \\
\hline $\begin{array}{l}7 \alpha \\
7 \beta\end{array}$ & $\begin{array}{l}1.57 \text { overlap } \\
1.39 \text { overlap }\end{array}$ & 34.1 & 26 & $1.08 \mathrm{~s}$ & 17.9 \\
\hline 8 & & 42.9 & 27 & $1.23 \mathrm{~s}$ & 24.4 \\
\hline $9 \alpha$ & $1.65 \mathrm{~m}$ & 48.5 & 28 & & 180.2 \\
\hline 10 & & 37.8 & 29 & $1.09 \mathrm{~d}(6.0)$ & 17.6 \\
\hline $\begin{array}{l}11 \alpha \\
11 \beta\end{array}$ & $\begin{array}{l}1.64 \mathrm{~m} \\
1.97 \mathrm{~m}\end{array}$ & 24.1 & $\begin{array}{l}30 \mathrm{a} \\
30 \mathrm{~b}\end{array}$ & $\begin{array}{l}4.50 \mathrm{dd}(3.2,11.2) \\
4.27 \mathrm{dd}(7.2,11.2)\end{array}$ & 68.2 \\
\hline 12 & $5.52 \mathrm{t}(3.2)$ & 126.7 & $1^{\prime}$ & & 167.5 \\
\hline 13 & & 139.3 & $2^{\prime}$ & $6.09 \mathrm{~d}(12.4)$ & 116.9 \\
\hline 14 & & 40.5 & $3^{\prime}$ & $7.03 \mathrm{~d}(12.4)$ & 144.5 \\
\hline $\begin{array}{l}15 \alpha \\
15 \beta\end{array}$ & $\begin{array}{l}1.25 \text { overlap } \\
2.35 \mathrm{~m}\end{array}$ & 29.1 & $4^{\prime}$ & & 127.1 \\
\hline $\begin{array}{l}16 \alpha \\
16 \beta\end{array}$ & $\begin{array}{l}2.14 \mathrm{~m} \\
2.04 \mathrm{~m}\end{array}$ & 25.4 & $5^{\prime}, 9^{\prime}$ & $8.09 \mathrm{~d}(8.4)$ & 134.0 \\
\hline 17 & & 48.3 & $6^{\prime}, 8^{\prime}$ & $7.22 \mathrm{~d}(8.4)$ & 116.5 \\
\hline $18 \beta$ & $2.7 \mathrm{~d}(11.6)$ & 53.8 & $7^{\prime}$ & & 161.1 \\
\hline $19 \alpha$ & 1.84 overlap & 34.9 & & & \\
\hline
\end{tabular}


The NMR data of 1 were quite similar to those of $3 \beta$-hydroxy-urs-12-en-28-oic-acid (3), except for signals for a nine-carbon chain [7,13] which was composed of one carbonyl $\left(\delta_{\mathrm{C}} 167.5\right)$, one double bond $\left(\delta_{\mathrm{H}} 6.09, \mathrm{~d}, J=12.8 \mathrm{~Hz}, \mathrm{H}-2^{\prime} ; \delta_{\mathrm{H}} 7.03, \mathrm{~d}, J=12.8 \mathrm{~Hz}, \mathrm{H}-3\right.$ '; $\delta_{\mathrm{C}} 116.4, \mathrm{C}-2^{\prime} ; \delta_{\mathrm{C}} 144.5$, C-3') and $p$-substituted phenol $\left(\delta_{\mathrm{H}} 8.09, \mathrm{~d}, J=8.4 \mathrm{~Hz}, \mathrm{H}-5{ }^{\prime}, \mathrm{H}-9{ }^{\prime} ; \delta_{\mathrm{H}} 7.22, \mathrm{~d}, J=8.4 \mathrm{~Hz}, \mathrm{H}-66^{\prime}, \mathrm{H}-8^{\prime}\right.$; $\delta_{\mathrm{C}} 134.0, \mathrm{C}-5 '$ ', C-9'; $\left.\delta_{\mathrm{C}} 116.5, \mathrm{C}-6{ }^{\prime}, \mathrm{C}-8^{\prime}, \delta_{\mathrm{C}} 161.7, \mathrm{C}-7^{\prime}\right)$. In the HMBC spectrum, the cross peaks of these two newly olefinic protons $\mathrm{H}-2^{\prime}$ and $\mathrm{H}-3^{\prime}$ to the conjugated carbonyl C-1' $\left(\delta_{\mathrm{C}} 167.5\right)$ and the aromatic carbon $\mathrm{C}-4^{\prime}\left(\delta_{\mathrm{C}} 127.1\right)$ of the $p$-substituted phenol, as well as the aromatic protons $\mathrm{H}-5^{\prime} / \mathrm{H}^{\prime} \mathrm{9}^{\prime}$ of the $p$-substituted phenol to the newly olefinic carbon $\mathrm{C}-3$ ', revealed that this double bond was fixed between the carbonyl and the $p$-substituted phenol, suggested the presence of a $p$-hydroxycinnamoyl group in 1. The coupling constant $J_{\mathrm{H}-2^{\prime}, \mathrm{H}-3^{\prime}}=12.4 \mathrm{~Hz}$ of H-2' and H-3', and the NOESY correlation between $\mathrm{H}-2$ ' and $\mathrm{H}-3$ ', indicated the $Z$-geometry of the double bond in the $p$-hydroxycinnamoyl group. The HMBC correlation of H-30 $\left(\delta_{\mathrm{H}} 4.50\right.$, dd, $J=3.2 \mathrm{~Hz}, 11.2 \mathrm{~Hz}, \mathrm{H}-30 \mathrm{a} ; \delta_{\mathrm{H}} 4.27$, dd, $J=7.2 \mathrm{~Hz}$, $11.2 \mathrm{~Hz}, \mathrm{H}-30 \mathrm{~b})$ to the carbonyl $\mathrm{C}-1^{\prime}$ of the $p$-Z-hydroxycinnamoyl group suggested the $p$-Z-hydroxycinnamoyl group was connected to $30-\mathrm{OH}$. HSQC, ${ }^{1} \mathrm{H}-{ }^{1} \mathrm{H}$ COSY, HMBC, and NOESY analysis (Figure 2) allowed us to assign compound $\mathbf{1}$ as $3 \beta$-hydroxy-urs-30-p-Z-hydroxycinnamoyloxy12-en-28-oic-acid.

Figure 2. ${ }^{1} \mathrm{H}-{ }^{1} \mathrm{H}$ COSY, Key HMBC, and NOESY correlations of compound $\mathbf{1}$.

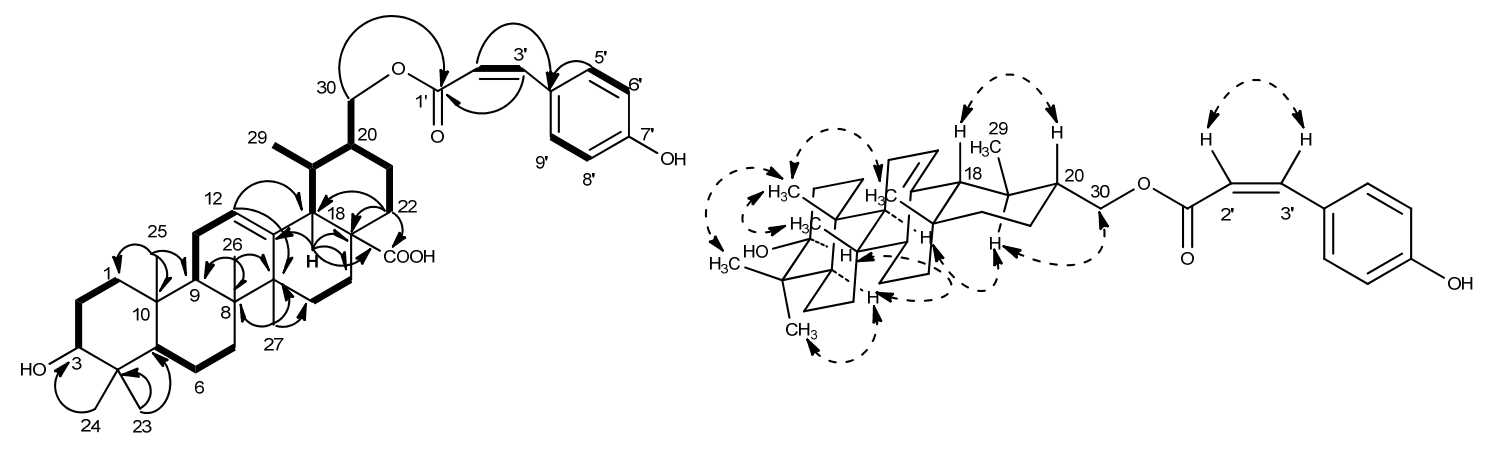

$$
\operatorname{HMBC}(\mathrm{H} \longrightarrow \mathrm{C}),{ }^{1} \mathrm{H}^{-1} \mathrm{H} \operatorname{COSY}(-) \text {, and } \operatorname{NOESY}\left(\bullet^{-\cdots}\right)
$$

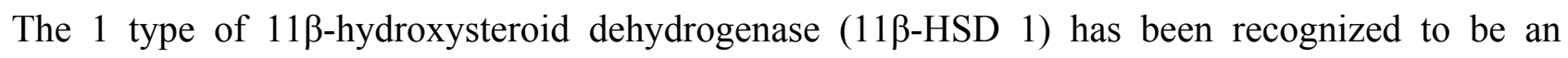

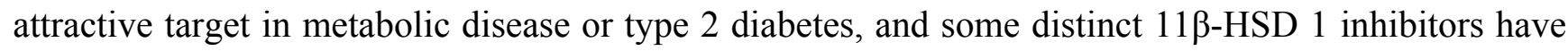
entered clinic trials [14]. Since pentacyclic triterpenoids were reported to be potential inhibitors of $11 \beta$-HSD 1 [15], compounds 1-4 were tested for their inhibitory activities against human 11 $\beta$-HSD 1 in vitro. Ursolic acid (4) showed stronger inhibitory activity on $11 \beta$-HSD1, with $\mathrm{IC}_{50}$ values of $1.5 \mu \mathrm{M}$, which was in accordance with the reported value [15]. Compound $\mathbf{3}$ displayed exceedingly weak inhibitory activity on $11 \beta$-HSD1 by comparison of the other triterpenoids in our assay. Compounds $\mathbf{1}$ and $\mathbf{2}$ did not show obvious activity against $11 \beta$-HSD 1 , which suggested that the variation of $\mathrm{CH}_{3}-30$ could reduce $11 \beta$-HSD 1 inhibitory activity. Structure-activity relationships of pentacyclic triterpenoid inhibitors of $11 \beta$-HSD 1 showed that the hydroxyl group at position C-19 could decrease $11 \beta$-HSD 1 inhibitory activity [15]. Our bioassay not only confirmed this conclusion, but also indicated that the variation of $\mathrm{CH}_{3}-30$ could also reduce the $11 \beta$-HSD 1 inhibitory activity. These results significantly extend our knowledge of the structure-activity relationship of ursolic acid derivatives as $11 \beta$-HSD 1 inhibitors. 


\section{Experimental}

\subsection{General Procedures}

Optical rotations were measured on a Perkin Elmer PE-341LC polarimeter. IR spectra were recorded as $\mathrm{KBr}$ disks on a Bruker Vertex 70 FT-IR spectrophotometer. HRESI-MS data were measured on an API QSTAR Pulsar spectrometer. NMR spectra were recorded using a Bruker AM-400 spectrometer, and the ${ }^{1} \mathrm{H}-\mathrm{NMR}$ and ${ }^{13} \mathrm{C}-\mathrm{NMR}$ chemical shifts were referenced to the solvent peaks for $\mathrm{C}_{5} \mathrm{D}_{5} \mathrm{~N}$ at $\delta_{\mathrm{H}} 8.74,7.58,7.22$, and $\delta_{\mathrm{C}} 150.35$, 135.91, 123.87. Silica gel (200-300 mesh, Qingdao Marine Chemical Inc., Qingdao, China), Amberchrom CG161M (75 $\mu \mathrm{m}$, Rohm and Haas Company, Philadelphia, PA, USA), ODS (50 $\mu \mathrm{m}$, YMC, Kyoto, Japan), and Sephadex LH-20 (Pharmacia Biotech AB, Stockholm, Sweden) were used for column chromatography. HPLC separation was performed on an instrument consisting of an Agilent 1100 controller, an Agilent 1100 pump, and an Agilent UV detector with an YMC $(250 \times 10 \mathrm{~mm}, 5 \mu \mathrm{m})$ preparative column. TLC was carried out on precoated silica gel $\mathrm{GF}_{254}$ plates. Spots were visualized under UV light (254 or $356 \mathrm{~nm}$ ) or by spraying with 5\% $\mathrm{H}_{2} \mathrm{SO}_{4}$ in $95 \%$ EtOH followed by heating.

\subsection{Plant Material}

The whole parts of T. viscidum were collected at Shiyan, Hubei Province, China, in June 2010, and identified by Prof. Changgong Zhang of School of Pharmacy, Tongji Medical College, Huazhong University of Science and Technology. The voucher specimen (No. 2010-0616) was deposited in the herbarium of Hubei Key Laboratory of Natural Medicinal Chemistry and Resource Evaluation, School of Pharmacy, Tongji Medical College, Huazhong University of Science and Technology.

\subsection{Extraction and Isolation}

The dried whole parts of $T$. viscidum $(50 \mathrm{Kg})$ were extracted with $70 \%$ acetone $(100 \mathrm{~L} \times 3$ times $)$ at the room temperature. After removal of the solvent, the crude extraction $(2.3 \mathrm{~kg})$ was suspended in $\mathrm{H}_{2} \mathrm{O}(5.0 \mathrm{~L})$ and partitioned successively with petroleum ether $\left(60-90^{\circ} \mathrm{C}\right), \mathrm{CHCl}_{3}$, and EtOAc to give petroleum ether, $\mathrm{CHCl}_{3}$, and EtOAc portions. The $\mathrm{CHCl}_{3}$ portion $(200 \mathrm{~g})$ was subjected to MCI gel column eluted with $\mathrm{MeOH} / \mathrm{H}_{2} \mathrm{O}(9: 1, \mathrm{v} / \mathrm{v})$, and then chromatographed on a silica gel column eluted with petroleum-acetone (50:1 to $0: 1, \mathrm{v} / \mathrm{v}$ ) to obtain seven fractions (A-G). Compound 9 (40 mg) was recrystallized from fraction A using EtOAc. Compound 4 (100 mg) was obtained by recrystallization in EtOH from fraction B. Fraction C was subjected to a Sephadex LH-20 column eluted with MeOH to give four subfractions $\left(\mathrm{C}_{1}-\mathrm{C}_{4}\right)$. Subfraction $\mathrm{C}_{2}$ was purified by semi-preparative HPLC (70\% MeCN in $\mathrm{H}_{2} \mathrm{O}$, flow rate $1.5 \mathrm{~mL} / \mathrm{min}$, wavelength $254 \mathrm{~nm}$ ) to obtain compounds 2 (5.0 $\mathrm{mg}$, retention time $\left.30 \mathrm{~min}\right)$ and 1 (6 mg, retention time $33 \mathrm{~min}$ ). Subfraction $\mathrm{C}_{3}$ was subjected to ODS column chromatography eluted with $80 \% \mathrm{MeOH}$ in $\mathrm{H}_{2} \mathrm{O}$, and then purified by semi-preparative $\mathrm{HPLC}\left(85 \% \mathrm{MeOH}\right.$ in $\mathrm{H}_{2} \mathrm{O}$, flow rate $1.5 \mathrm{~mL} / \mathrm{min}$, wavelength $254 \mathrm{~nm}$ ) to yield compound $3(7 \mathrm{mg}$, retention time $45 \mathrm{~min})$. Fraction D was applied to RP- $\mathrm{C}_{18}$ gel column eluted with $\mathrm{MeOH} / \mathrm{H}_{2} \mathrm{O}$ (1:5 to 1:0, v/v), followed by chromatography over repeated silica gel column $\left(\mathrm{CHCl}_{3} / \mathrm{MeOH}, 60: 1\right.$, v/v) to afford compound 5 $(8 \mathrm{mg})$. Fraction E was subjected to $\mathrm{RP}_{-} \mathrm{C}_{18}$ gel column eluted with $\mathrm{MeOH} / \mathrm{H}_{2} \mathrm{O}$ (1:5 to $1: 0$, v/v), 
followed by chromatography over silica gel and finally purified by semi-preparative HPLC (40\% $\mathrm{MeOH}$ in $\mathrm{H}_{2} \mathrm{O}$, flow rate $1.5 \mathrm{~mL} / \mathrm{min}$, wavelength $205 \mathrm{~nm}$ ) to get compounds 6 (6 mg, retention time $43 \mathrm{~min}$ ) and 7 (9 mg, retention time $46 \mathrm{~min}$ ). Fraction F was subjected to a Sephadex LH-20 column eluted with $\mathrm{MeOH}$, followed by chromatography over silica gel eluted with petroleum/acetone $(15: 1, \mathrm{v} / \mathrm{v})$ to get compound $\mathbf{8}(10 \mathrm{mg})$. Compound $\mathbf{1 0}(100 \mathrm{mg})$ was directly crystallized from fraction $\mathrm{F}$.

33-hydroxy-urs-30-p-Z-hydroxycinnamoyloxy-12-en-28-oic-acid (1). Amorphous powder. $[\alpha]_{\mathrm{D}}^{25}:+27$ $\left(c=0.85\right.$, THF); UV (THF) $\lambda_{\max }(\log \varepsilon) \mathrm{nm}: 312$ (3.33), 208 (3.39); IR (KBr) $v_{\max }$ 3729, 2924. 1685, 1601, 1512, 1457, 1384, 1260, 1024, and $772 \mathrm{~cm}^{-1} ;{ }^{1} \mathrm{H}-\mathrm{NMR}\left(\mathrm{C}_{5} \mathrm{D}_{5} \mathrm{~N}, 400 \mathrm{MHz}\right)$ and ${ }^{13} \mathrm{C}-\mathrm{NMR}$ $\left(\mathrm{C}_{5} \mathrm{D}_{5} \mathrm{~N}, 100 \mathrm{MHz}\right)$ see Table 1; HRESIMS m/z: $641.3799[\mathrm{M}+\mathrm{Na}]^{+}$(calcd. for $\mathrm{C}_{39} \mathrm{H}_{54} \mathrm{O}_{6} \mathrm{Na}^{+}, 641.3818$ ).

\subsection{1ß-HSD1 Inhibitory Assays}

The scintillation proximity assay (SPA) was used to analyze the inhibitory activities of compounds 1-4 on human $11 \beta$-HSD1. Microsomes containing $11 \beta$-HSD1 were used according to the reported studies [16]. The full-length cDNAs of human $11 \beta$-HSD1 were isolated from the cDNA libraries provided by NIH Mammalian Gene Collection and cloned in pcDNA3 expression plasmid. HEK-293 cells were transformed with the pcDNA3-derived expression plasmid. Transformed cells were screened by $700 \mu \mathrm{g} / \mathrm{mL}$ G418. The microsomal fraction, which stably expressed 11 $\beta$-HSD1, was prepared from the HEK-293 cells, and then was used for SPA. Briefly, microsomes were incubated with NADPH and $\left[{ }^{3} \mathrm{H}\right]$ cortisone. The product, $\left[{ }^{3} \mathrm{H}\right]$ cortisol, was specifically captured by monoclonal antibody coupling to protein A-coated SPA beads. $\mathrm{IC}_{50}(\mathrm{X} \pm \mathrm{SD}, \mathrm{n}=3)$ values were calculated by using Prism Version 4 (GraphPad Software, San Diego, CA, USA).

\section{Conclusions}

A new ursane-type triterpenoid, 3 $\beta$-hydroxy-urs-30- $p$-Z-hydroxycinnamoyloxy-12-en-28-oic-acid (1), was isolated from the whole parts of $T$. viscidum together with three known triterpenoids, $3 \beta$-hydroxy-urs-30- $p$ - $E$-hydroxycinnamoyloxy-12-en-28-oic-acid (2), 2 $\alpha, 3 \beta, 19 \alpha$-trihydroxy-urs-12-en28-oic-acid (3), ursolic acid (4), four known lignans, pinoresinol (5), $9 \alpha$-hydroxypinoresinol (6), (+)-medioresinol (7), (+)-kobusin (8), and two steroids, $\beta$-sitosterol (9), daucosterol (10). Their structures were established by a combination of spectroscopic data analysis, and comparison with literature data. Compounds 2-10 were isolated from T. viscidum for the first time. Compounds 1-4 were tested for $11 \beta$-HSD1 inhibition activities in vitro, whereby compound 4 showed stronger inhibitory activity, while compounds $\mathbf{1}-\mathbf{3}$ did not show obvious $11 \beta$-HSD1 inhibitory activities.

\section{Supplementary Materials}

Supplementary materials can be accessed at: http://www.mdpi.com/1420-3049/18/1/1262/s1.

\section{Acknowledgments}

This work was financially supported by National Natural Science Foundation of China (No. 81202423), Science Foundation for the Excellent Youth Scholars, Health Department of Hubei 
Province, China (QJX2010-2), Scientific Research Foundation for the Returned Oversea Chinese Scholars, State Education Ministry of China (2010-1561-40th), Program for New Century Excellent Talents in University (NCET-2008-0224), and National Innovation Experiment Program for University Students, Huazhong University of Science and Technology (to Y.S.).

\section{References}

1. State Administration of Traditional Chinese Medicine. Zhong Hua Ben Cao; Shanghai Science and Technology Publishing Company: Shanghai, China, 1999; pp. 6239-6240.

2. Chen, Y.P.; Li, C.M.; Sun, H.D. The diterpenoid from Teucrium viscidum. Acta Botanica Yunnanica 1990, 12, 110.

3. Fujita, E.; Uchida, I.; Fujita, T.; Masaki, N.; Osaki, K. Teucvin, a novel furanoid norditerpene from Teucrium uiscidum var. miquelianum. J. Chem. Soc. Chem. Commun. 1973, 20, 793-794.

4. Node, M.; Sai, M.; Fujita, E. Isolation of the diterpenoid teuflin (6-epiteucvin) from Teucrium viscidum var. miquelianum. Phytochemistry 1981, 20, 757-760.

5. Uchida, I.; Fujita, T.; Fujita, E. Terpenoids-XXXIV: Teucvidin, a minor norditerpene from Teucrium viscidum var. miquelianum. Tetrahedron 1975, 31, 841-848.

6. Siddiqui, B.S.; Begum, S. Two triterpenoids from the leaves of Plumeria obtusa. Phytochemistry 1999, 52, 1111-1115.

7. Jang, D.S.; Kim, J.M.; Lee, G.Y.; Kim, J.; Kim, J.S. Ursane-type triterpenoids from the aerial parts of Potentilla discolor. Agric. Chem. Biotechnol. 2006, 49, 48-50.

8. Cowan, S.; Stewart, M.; Abbiw, D.K.; Latif, Z.; Sarker, S.D.; Nash, R.J. Lignans from Strophanthus gratus. Fitoterapia 2001, 72, 80-82.

9. Li, Y.S.; Wang, Z.T.; Zhang, M.; Luo, S.D.; Chen, J.J. A new pinoresinol-type lignan from Ligularia kanaitizensis. Nat. Prod. Res. 2005, 19, 125-129.

10. Khan, K.A.; Shoeb, A. A lignan from Lonicera hypoleuca. Phytochemistry 1985, 24, 628-630.

11. Latip, J.; Hartley, T.G.; Waterman, P.G. Lignans and coumarins metabolites from Melicopehayesii. Phytochemistry 1999, 51, 107-110.

12. Al-Qudah, M.A.; Zarga, M.H.A. Chemical constituents of Sisymbrium irio L. from Jordan. Nat. Prod. Res. 2010, 24, 448-456.

13. Thuong, P.T.; Lee, C.H.; Dao, T.T.; Nguyen, P.H.; Kim, W.G.; Lee, S.J.; Oh, W.K. Triterpenoids from the leaves of Diospyros kaki (Persimmon) and their inhibitory effects on protein tyrosine phosphatase 1B. J. Nat. Prod. 2008, 71, 1775-1778.

14. Feng, Y.; Huang, S.L.; Dou, W.; Zhang, S.; Chen, J.H.; Shen, Y.; Shen, J.H.; Leng, Y. Emodin, a natural product, selectively inhibits $11 \beta$-hydroxysteroid dehydrogenase type 1 and ameliorates metabolic disorder in diet-induced obese mice. Br. J. Pharmacol. 2010, 161, 113-126.

15. Rollinger, J.M.; Kratschmar, D.V.; Schuster, D.; Pfisterer, P.H.; Gumy, C.; Aubry, E.M.; Brandstoter, S.; Stuppner, H.; Wolber, G.; Odermatt, A. 11 $\beta$-Hydroxysteroid dehydrogenase 1 inhibiting constituents from Eriobotrya japonica revealed by bioactivity-guided isolation and computational approaches. Bioorg. Med. Chem. 2010, 18, 1507-1515. 
16. Yang, H.; Dou, W.; Lou, J.; Leng, Y.; Shen, J. Discovery of novel inhibitors of $11 \beta$-hydroxysteroid dehydrogenase type 1 by docking and pharmacophore modeling. Bioorg. Med. Chem. Lett. 2008, 18, 1340-1345.

Sample Availability: Not available.

(C) 2013 by the authors; licensee MDPI, Basel, Switzerland. This article is an open access article distributed under the terms and conditions of the Creative Commons Attribution license (http://creativecommons.org/licenses/by/3.0/). 